\title{
Rethinking territoriality concept on public space after pandemic COVID-19
}

\author{
Sherly de Yong ${ }^{1}$, Murni Rachmawati ${ }^{2}$, Ima Defiana ${ }^{3}$ \\ ${ }^{1,2,3}$ Department of Architecture, Institut Teknologi Sepuluh Nopember, Surabaya, Indonesia \\ ${ }^{1}$ Department of Interior Design, Petra Christian University, Surabaya, Indonesia
}

\begin{abstract}
Article Info
Article history:

Received Jan 20, 2021

Revised Aug 7, 2021

Accepted Aug 24, 2021

Keywords:

Coronavirus

Interior

Pandemic

Social distance

Space

ABSTRACT

The spread and pandemic of coronavirus disease (COVID-19) that is currently happening in the world, has led to new policy steps in the security of public spaces to reduce the transmission of COVID-19 and protect public health. There is new adaptation in the policies while using space like limiting the use of public spaces, increasing social distancing between people or creating territory. Territory means specific area where are claimed or maintained (can be physically, through ruler or symbols). Territory can give a sense of security to the users. Therefore, this paper give insight and rethinking the territory concept as sense of security in interior public space and built environment where people expect to see strangers in this space. The methods in this paper are literature review method by collecting and synthesizing previous research using integrative approach. For the result is territory concept achieved as part of protection to the users in the build environment with mechanisms that should be applied in each type: the boundary between areas; limitation to the symbolic; supervision and control of space.
\end{abstract}

This is an open access article under the CC BY-SA license.

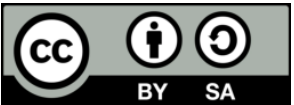

\section{Corresponding Author:}

Sherly de Yong

Department of Architecture

Institut Teknologi Sepuluh Nopember

Campus ITS Sukolilo, Jl. Raya ITS, Surabaya-Indonesia. J1 Siwalankerto 121-131 Surabaya, Indonesia

Email: sherly_de_yong@petra.ac.id

\section{INTRODUCTION}

COVID-19 or Corona (CO) Virus (VI) Disease (D), is a disease that was found in 2019 with the name: 2019 novel coronavirus or 2019-nCoV. This virus is similar with Severe Acute Respiratory Syndrome (SARS) and other flu virus. The contagion of COVID-19 is from human contact, air transmission (especially in the indoor) and contaminated objects (like money, phone, interior furniture surface) [1]. World Health Organization has declared COVID-19 as a pandemic on 12th March 2020 because the spread of COVID-19 has become worldwide. In the effort to control the COVID-19 outbreak and reducing the widespread of COVID-19 in Indonesia, the government has adopted few policies such large scale social restrictions (LSSR), Work and School from Home, restrict activities in public places-space facilities and the implementation of clean-healthy living behavior [2]-[4]. The immediate dan precaution policies by Indonesia government have made economic and social disruption and crisis on public health, food system, and world of work and school. Therefore, the government made a new strategy that focusing in the new normal protocol and personal protection as step to anticipate the widespread of COVID-19 in the public space and built environment [5].

The new normal protocols such as controlling the users flow inside the public space and built environment, protocols and protection for the officers and employees of the public space, and protocols 
activities in the public space and built environment. The personal protection including the intensive and extensive cleaning, disinfectant and sanitizing the facility, social-physical distancing system and temperature and health check [5]. To face a pandemic like this, public space and built environment need to adapt the new normal protocols. Architecture and interior designers are expected to provide design solutions that enhance safety and security and help prevent the health threats like COVID-19 in the future [6], [7]. These new adaptations in the public space and built environment are changing our way of using the space by limiting the activity and use of the public space and built environment, increasing physical-social distancing between people, and creating territory.

Delaney in de Yong [8], [9] described territory as providing security to those inside from those ever present dangers located outside. While Rapoport and Pearson in de Yong [9], [10] defined territory as area where are claimed or maintained through ruler-symbol and physical attribute. Before COVID-19, the territory concept applied in the public space is such no boundary or surveillance and less defensible space. But after COVID-19 and the new normal protocol, there is changing, and new practice emerge in the practice territory. This paper aims to give insight and rethinking the territory concept as sense of security in the public space and built environment where people expect to see strangers in this space.

\section{RESEARCH METHOD}

The research methods in this paper are literature review and site observation method. The literature review approach for this paper will be the integrative or critical review approach through computer search, with the purpose of this review is to assess critique and synthesize the literature on a research topic in a way that enables new theoretical frameworks and perspectives to emerge. There will be 4 phase of literature review: design (phase 1), conduct (phase 2), analysis (phase 3) and structuring and writing the review (phase 4) [11]. The framework from the literature review data will be used as guidelines and tools to analyze the site using observation method to create a conclusion of rethinking territory after COVID-19.

\subsection{The literature review method}

The primary databases that will be used in this literature review method will be utilized to retrieve territory for public space and built environment literature presented in this review were ProQuest, ScienceDirect, Lens.org and Google Scholar. The keywords for search terms, used both separately and in combination, included: "territory," "territoriality," "territorialization," "COVID-19," "coronavirus," "SARSCoV-2," "public space," "built environment," "architecture," "security," and "interior." Only articles with qualitative method and presented in Indonesia and English language were included. There are 52 documents reviewed. There are four phases for this literature review method with integrative review approach [11].

a). Phase 1: designing the review. In this phase is about deciding the purpose, specific research question and type of approach. The explanation in this phase will answer regarding the aim, the importance and why this review should be conducted and its contribution. There are 52 articles reviewed.

b). Phase 2: conducting the review; in this phase, is about testing the search terms and inclusion criteria on a smaller sample with the focus on the definition and types and concept of territory. In this phase, only 30 articles were included in this journal.

c). Phase 3: analysis; in this phase is about how articles will be used to conduct an appropriate analysis. The data abstracted from descriptive information such of topic or from the effect and findings.

d). Phase 4: writing the review; in this phase is creating descriptive summaries of research regarding the number of articles published, topics covered, citations analyzed, authors represented, method used. The data collecting in this review will be a combine perspectives and insights from different field. The three field will be collected as literature data. The literature data will be analyzed and examined based on the ideas and relationships within the issue to create a new conceptual framework.

\subsection{The site observation method}

The site observation is the next method that will be used in this paper. The purpose of this method is to create new conceptual framework based on the issue territory concept after COVID-19. This method involves observing people in their natural activities and usual context such as public space and built environments [12], [13]. With direct observation the researcher is present and indirect observation the activities may be recorded using photo digital recording. The steps for this site observation will be: i) define objectives and context of the observation; ii) define the method of observation (using taking notes and direct observation) and the method of recording information (using digital photo and video recording) in the public space (shopping mall and church). The data was collected between March 2020-June 2020; iii) hypothesize and explanation for the phenomenon; iv) analyze the data gathered and create a list of insights derived from observation to create discussion and a new conceptual framework as the result of rethinking the territoriality concept on public space. 


\section{RESULTS AND DISCUSSION}

The aim for literature review of territoriality concept is to create a framework regarding the territoriality concept before COVID-19 (phase 1). The literature review started by describing the territoriality concept before COVID-19 from the introduction and background, definition, function, type, and mechanism from various studies and the topic regarding the public space and built environment (phase 2). The data will be analyzed using descriptive method (phase 3). Then the result is written in a conceptual framework (phase 4). Research report on the COVID-19, territoriality and build environment is shown in Table 1 (see in Appendix).

\subsection{Literature review analysis of territoriality concept}

Based on Pastalan in Lang [14], The concept territoriality is associated with the territory of human in this case is user of space. The territory defined as a restricted space where a person or group of people uses and maintains it as an exclusive space and involves identification, psychological environmental place, symbolizing it with possessive conduct and organizing objects in the area. While J. Douglas Porteous (1976) in Zubaidi and de Yong [9], [15] defined the concept of territoriality as a spatial behavior that involves special control of space by individuals or groups of users that are intraspecific in nature involving animosity and giving the individual or group of users the policy to use and defend the space. Altman in Lang [14] defined territorial behavior as a mechanism of self-limiting and self-regulating behavior that involves personalizing or claiming a place or object and communicating that the place is already owned by a person or group of user. Delaney in de Yong [8], [9] describe territory as providing security to those inside from those ever present dangers located outside. While Rapoport in de Yong [9], [10] defined territory as area where are claimed or maintained through ruler-symbol and physical attribute. As the result of this literature review describe that the concept of territoriality is associated with the activity of users and spatial behavior of users while defending space using symbols, identity, and personalization in the space itself. For the conclusion of the territoriality concept, please refer to Figure 1. Based on this, the characteristic of territoriality concept is: (i) marking in the area and creating boundary; (ii) personalization on the area; (iii) Truth to defend the area; (iv) Fulfilment in the basic physiological, cognitive, and aesthetic needs. Territoriality has a function to fulfil the human psychological and social needs, which is as mechanism to sustain life (by controlling the space), provide a sense of security and identity, creating personal integrity and creating invisible frame for the user while socializing in the environment. There are two mechanism in the territorial concept, which is the defense mechanism and personalization mechanism [14], [16]. In conclusion, territoriality is associated with the activity and spatial behavior of someone in defending its territory.

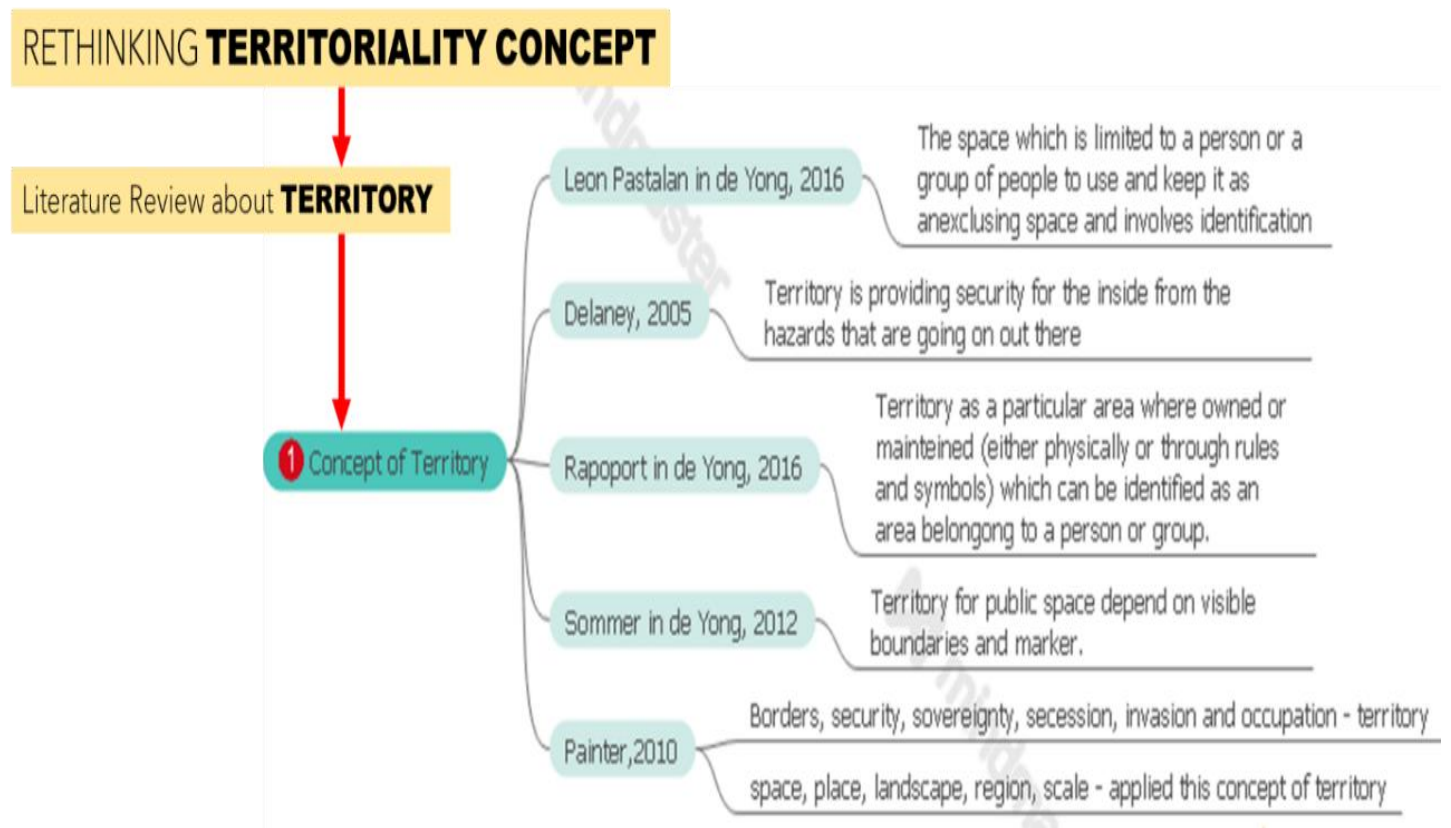

Figure 1. Conclusion for the concept of territoriality 
Sommer [17] defined that there are three types of territoriality: personal space, home base (defensible active space), and home range (behavior setting from the activity). Hussein El-Sharkawy in Lang [14] defined four types of territoriality: attached (space bubble), central (personalization space), supporting (semipublic but can be owned by organization) and peripheral (public space). Altman in Hadinugroho [18], [19] define three types of territoriality: primary (owned and personalized by the owner), secondary (cannot be owned but still can be personalized) and public (used by a lot of users). When we are doing personalization in a space especially personal space, there are few factors as reference in using the personal space: status, gender, physic, age, personality, culture, environment condition [20]. The control mechanism in territory is: primary (real boundary, symbolic boundary, clear area boundary, control and clear surveillance, more defensible, more personalization), secondary primary (not really real boundary, could have symbolic boundary, grey area boundary, could have control and partly clear surveillance, defensible, personalization) and public primary (no real boundary, no symbolic boundary, no clear area boundary, no control and clear surveillance, less defensible, no personalization) [16]. The conclusion of the territoriality concept can be seen in Figure 1 and 2.

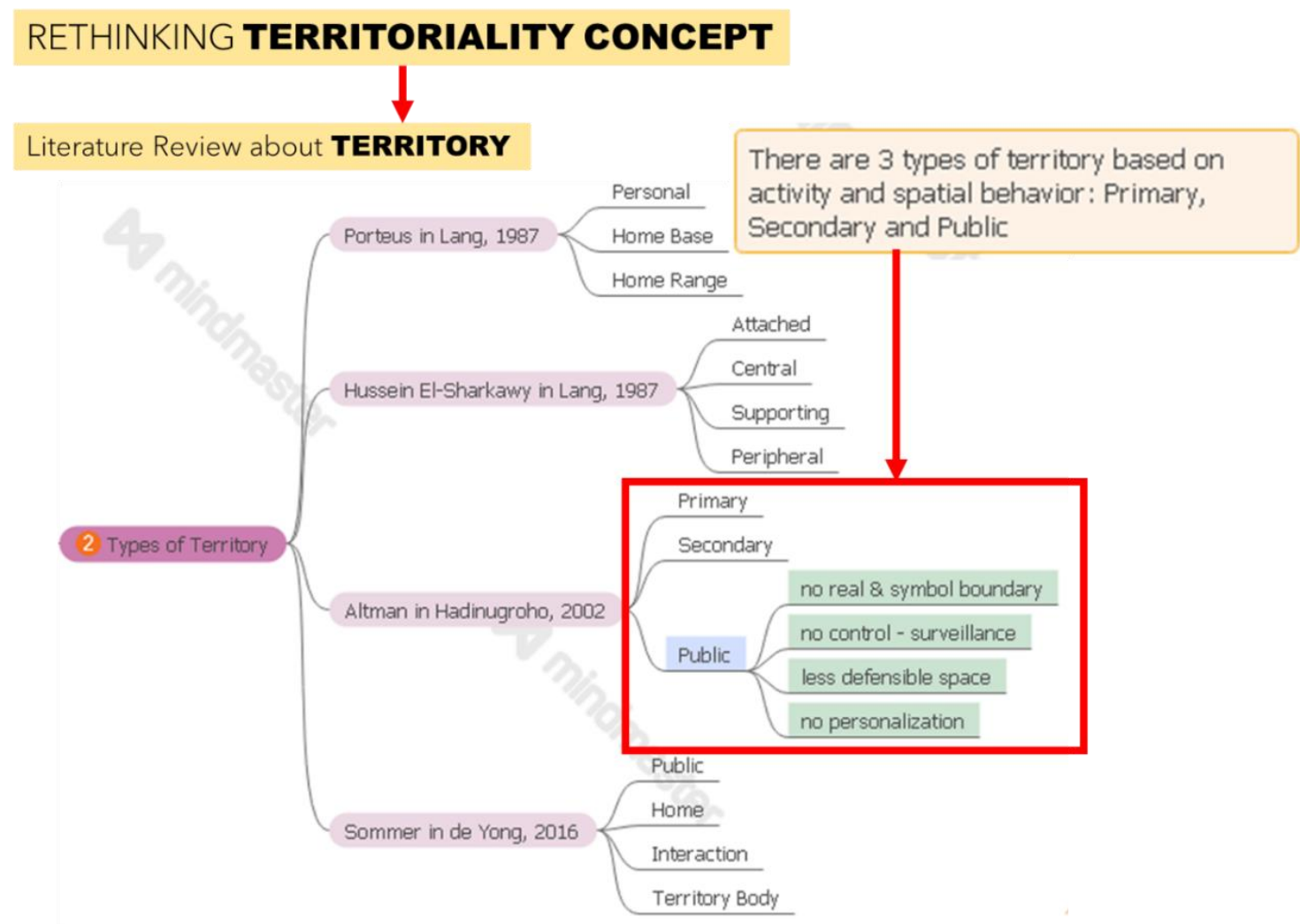

Figure 2. Conclusion for the mechanism of territoriality

\subsection{Literature review analysis of COVID-19 and built environment}

COVID-19 stands for Corona (CO) Virus (VI) Disease (D) is a new virus that is associated with the same virus family as Severe Acute Respiratory Syndrome (SARS) and several other types of flu. Symptoms when exposed to this disease are fever, cough and shortness of breath. In more severe cases, the infection can cause pneumonia or difficulty breathing, and even be fatal. These symptoms are similar to those of the flu (influenza) or the common cold, so testing is needed to confirm whether a person has COVID-19. [21] The virus is transmitted by direct contact with respiratory droplets from an infected person (generated through coughing and sneezing). Individuals can also become infected after touching a contaminated surface and then touching their face (eg, eyes, nose, and mouth). The COVID-19 virus can survive on surfaces for several hours but can be killed with a simple disinfectant. Apart from respiratory droplets, this virus can also spread through aerosols with smaller particles (especially in indoor spaces) and stay in the air for several hours. The virus is more susceptible and affects older people, or people with pre-existing medical conditions, such as diabetes and heart disease [21]. 
Therefore, there are several rules that can be applied through the spatial layout to help reduce the spread of this virus through the new spatial layout. For example, in the work environment: avoiding eating out, two meters of social distancing, use of transparent screens around the table, innovative hands-free door handles, opening windows to increase air circulation, cleaning regularly and thoroughly, implementing flexible working hours, and meetings with large distances as in the following example. The COVID-19 pandemic has changed user behavior when indoors. Architects and future users will pay more attention to climate, health, architecture, and environmental issues and how these four affect one another. The design of future structures will certainly consider sustainability, health and flexibility more so that future structures can be useful to prevent the spread of viruses like this again [7]. In conclusion, COVID-19 has brought impact in the public space and built environment so there will be changing in the public space and built environment in the future.

\subsection{Site observation of territoriality concept in public space (shopping mall and church)}

The Objective for the site observation method is to observe and creating a list of insight regarding the changing in the built environment after COVID-19. The public space sample that is use in this paper is a shopping mall and a church in Surabaya-Indonesia. The data was collected between March 2020 through June 2020. The more detailed pictures of the changing of the shopping mall and church are shown in Figure 3 (see in Appendix).

Based on the above site observation, then there are changing in the public space-built environment (in this study case is shopping mall and church). The changing in the control mechanism of territoriality, especially in the Public Primary. Before COVID-19, the mechanism of territoriality is no real boundary, no symbolic boundary, no clear area boundary, no control, and clear surveillance, less defensible, no personalization). But after COVID-19, there are real, symbolic, and clear area boundary; controlling and clear surveillance; and more defensible space. The changing especially applied in the outside perimeter, through the inside public space and signage for reminding the user to keep physical-social distancing and using mask all the time.

\section{CONCLUSION}

Based on the literature review of territoriality space and COVID-19 and built environment, and site observation, it is clearly show that there are changing in the concept of territoriality for public space. Before COVID-19, the territory concept applied in the public space is such no boundary or surveillance and less defensible space. But after COVID-19 and the new normal protocol, there is changing, and new practice emerge in the practice territory.

Even though there are still limitation in this study (not much study for this issues), we still can see in the site observation's pictures that there are some changing in the public space of shopping mall and church. In conclusion, we expect to see strangers and should have the freedom while using the public space, but the new normal mechanism for territoriality concept (real, symbolic, and clear area boundary; controlling and clear surveillance; and more defensible space) is changing the user while using the space. We still need more study in future research regarding this matter. The spread of the future disease, the human detachment, culture, behavior, virtual world, and even local climate can implicate the future territoriality concept. We still need to develop more evidence using different method to creating new normal framework and new position emerge for territoriality concept.

\section{ACKNOWLEDGEMENTS}

This study was supported by Institut Teknologi Sepuluh Nopember and Petra Christian University Surabaya-Indonesia. The authors are grateful to their support.

\section{REFERENCES}

[1] WHO, "The best time to prevent the next pandemic is now: countries join voices for better emergency preparedness." https:/www.who.int/news/item/01-10-2020-the-best-time-to-prevent-the-next-pandemic-is-nowcountries-join-voices-for-better-emergency-preparedness (accessed Dec. 06, 2020).

[2] Kemenkes RI, "Guidelines for the Prevention and Control of Coronavirus Disease (COVID-19), (In Indonesia: Pedoman Pencegahan dan Pengendalian Coronavirus Disease (COVID-19) Revisi ke-5," 2020, [Online]. Available: 19_13_Juli_2020_1.pdf.

[3] Kemenkes RI, "Regulation of the Minister of Health of the Republic of Indonesia Guidelines for Large-scale Social Limitation in the Context of Accelerating Handling of Corona Virus Disease 2019," 2020. Accessed: Aug. 07, 2021. [Online]. Available: http://hukor.kemkes.go.id/uploads/produk_hukum/PMK_No_9_Th_2020_ttg_Pedoman_Pembatasan_Sosial_Bers 
kala_Besar_Dalam_Penanganan_COVID-19.pdf.

[4] N. A. Pascawati and T. B. T. Satoto, "Public knowledge, attitudes and practices towards COVID-19," Int. J. Public Heal. Sci., vol. 9, no. 4, pp. 292-302, 2020, doi: 10.11591/ijphs.v9i4.20539.

[5] PT. Angkasa Pura 1 Persero, "NEW NORMAL PROTOCOL \#CovidSafeBUMN \#terbanglagi," 2020, [Online]. Available: www.ap1.co.id.

[6] L. \& R. A.-R. O’Shea, "Design and Security in the Built Environment," Fairchild Books, 2009.

[7] G. Ateek, "Future of Sustainable Architecture: Rethinking COVID-19 a Pandemic or turning point?," 2020. https://www.researchgate.net/publication/342522054_Future_of_Sustainable_Architecture_Rethinking_COVID19_a_Pandemic_or_turning_point (accessed Jan. 12, 2021).

[8] D. Delaney, "Territory: A Short Introduction," Blackwell Publishing Ltd, 2008.

[9] S. De Yong, "Reterritorializing Chinese Living Space Apartments In Singapore," Dimens. Inter., vol. 9, no. 1, pp. 46-56, Sep. 2012, doi: 10.9744/interior.9.1.46-56.

[10] M. P. Pearson and C. Richards, "Architecture and Order: Approaches to Social Space," 2nd ed., vol. 100, no. 2. London and New York: Routledge, 2005.

[11] H. Snyder, "Literature review as a research methodology: An overview and guidelines," J. Bus. Res., vol. 104, pp. 333-339, Nov. 2019, doi: 10.1016/j.jbusres.2019.07.039.

[12] R. Curedale, "Design Thinking: process \& method guide," Design Community College Incorporated, 2018.

[13] R. Curedale, "50 Selected Design Methods: To Transform Your Design. Design Community College Incorporated, 2013.

[14] J. Lang, "Creating architectural theory," Van Nostrand Reinhold Company, 1987.

[15] F. Zubaidi, "Types and Patterns of Territory in the Traditional Settlement of Ngata Toro," J. Archit., vol. 18, no. 2, p. 123, 2019, doi: 10.12962/j2355262x.v18i2.a6029.

[16] S. de Yong and E. D. Tedjokoesoemo, "Territoriality concept for crime prevention in interior design," Soc. Sci., vol. 11, no. 15, pp. 3808-3813, 2016, doi: 10.3923/sscience.2016.3808.3813.

[17] Robert Sommer, "Personal Space; Updated, The Behavioral Basis of Design. Bosko Books, 2008.

[18] K. D. Moore, "Culture meaning architecture: critical reflections on the work of Amos Rapoport," Ethnoscapes. Ashgate, pp. xxix, 277, 2000.

[19] I. D. L. Hadinugroho, "Space and behavior: an architectural study (In Indonesia: Ruang Dan Perilaku: Suatu Kajian Arsitektural)," USU Digital Library, 2004, [Online]. Available: repository.usu.ac.id/bitstream/.../1/arsitektur-dwi3.pdf (accessed Jun. 20, 2021).

[20] S. Augustin, "Place Advantage," John Wiley \& Sons, Inc./Business, 2009.

[21] W. World Health Organizatiion, "Key Messages and Actions for COVID-19 Prevention and Control in Schools," 2020.

[22] F. Zubaidi, "Territoriality in the Traditional Context," Psychol. Behav. Sci., vol. 2, no. 3, p. 89, 2013, doi: 10.11648/j.pbs.20130203.12.

[23] J. Painter, "Rethinking Territory," Antipod. J., vol. 42, no. 5, pp. 1090-1118, Nov. 2010, doi: 10.1111/j.14678330.2010.00795.x.

[24] J. Honey-Rosés et al., "The Impact of COVID-19 on Public Space: A Review of the Emerging Questions," OSF Prepr., vol. 00, no. 00, 2020, doi: 10.31219/osf.io/rf7xa.

[25] A. Basista and A. Jasiński, "architecture and urban planning Public space or safe space-remarks during the COVID19 pandemic," Tech. Trans., vol. 117, no. 1, Jan. 2020, doi: 10.37705/TechTrans/e2020020.

[26] N. Megahed, E. G.-S. C. and Society, and undefined 2020, "Antivirus-built environment: Lessons learned from Covid-19 pandemic," Elsevier, Accessed: Oct. 08, 2020. [Online]. Available: https://www.sciencedirect.com/science/article/pii/S2210670720305710.

[27] J. Van Bavel et al., "Using social and behavioural science to support COVID-19 pandemic response," Nat. Hum. Behav., vol. 4, no. May 2020, pp. 460-471, 2020.

[28] M. Hakovirta and N. Denuwara, "How COVID-19 redefines the concept of sustainability," Sustainability (Switzerland), vol. 12, no. 9, May 01, 2020, doi: 10.3390/su12093727.

[29] S. Lai, F. Leone, and C. Zoppi, "COVID-19 and spatial planning," TeMA - J. L. Use, Mobil. Environ., pp. 213-246, 2020, doi: 10.6092/1970-9870/6846.

[30] L. Cirrincione et al., "COVID-19 Pandemic: Prevention and protection measures to be adopted at the workplace," Sustain., vol. 12, no. 9, 2020, doi: 10.3390/SU12093603.

[31] A. Madanipour, "Rethinking public space: between rhetoric and reality," Urban Des. Int., vol. 24, no. 1, pp. 38-46, Mar. 2019, doi: 10.1057/s41289-019-00087-5.

[32] F. Pirlone and I. Spadaro, "The resilient city and adapting to the health emergency," TeMA - J. L. Use, Mobil. Environ., no. Covid-19 vs City-20, pp. 305-314, 2020, doi: 10.6092/1970-9870/6856.

[33] M. Batty, "The Coronavirus crisis: What will the post-pandemic city look like?," Environment and Planning B: Urban Analytics and City Science, vol. 47, no. 4, pp. 547-552, Jun. 01, 2020, doi: 10.1177/2399808320926912.

[34] P. Atmodiwirjo and Y. A. Yatmo, "Shifting Interiority: Changing Encounters With Our Environment," Interiority, vol. 3, no. 2, pp. 117-120, Jul. 2020, doi: 10.7454/in.v3i2.106. 


\section{APPENDIX}

Table 1. Research report on the COVID-19, territoriality and build environment

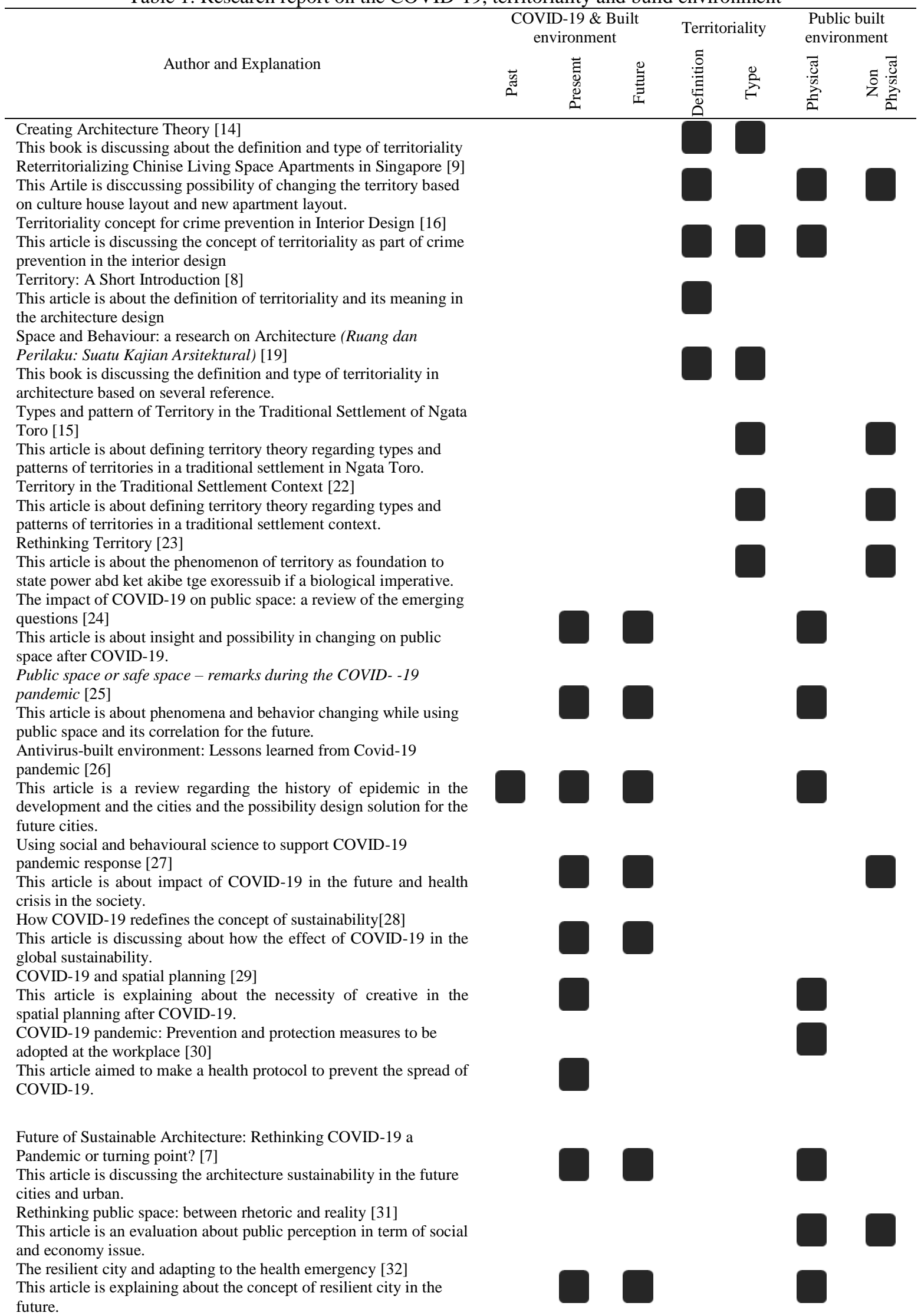




Author and Explanation
The Coronavirus crisis: What will the post-pandemic city look
like?.[33]
This article is predicting the possibility of urban sprawl to the small
Sities.
[34]
This article is explaining the adaptation in the interior after
pandemic.

\section{Outside perimeter of Shopping Mall}

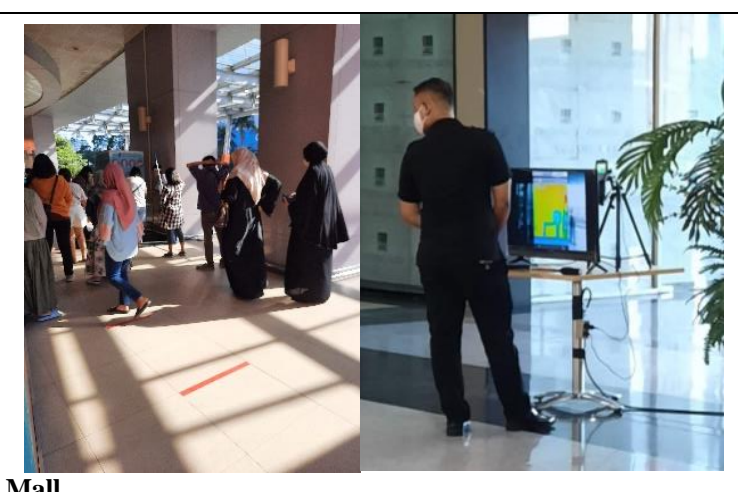

This picture is showing the new-normal protocol outside the building that demanding the user is lining up to wash their hand and there is temperature check in the front door before entering the Shopping Mall. This is showing that there are control and surveillance before entering the Shopping Mall

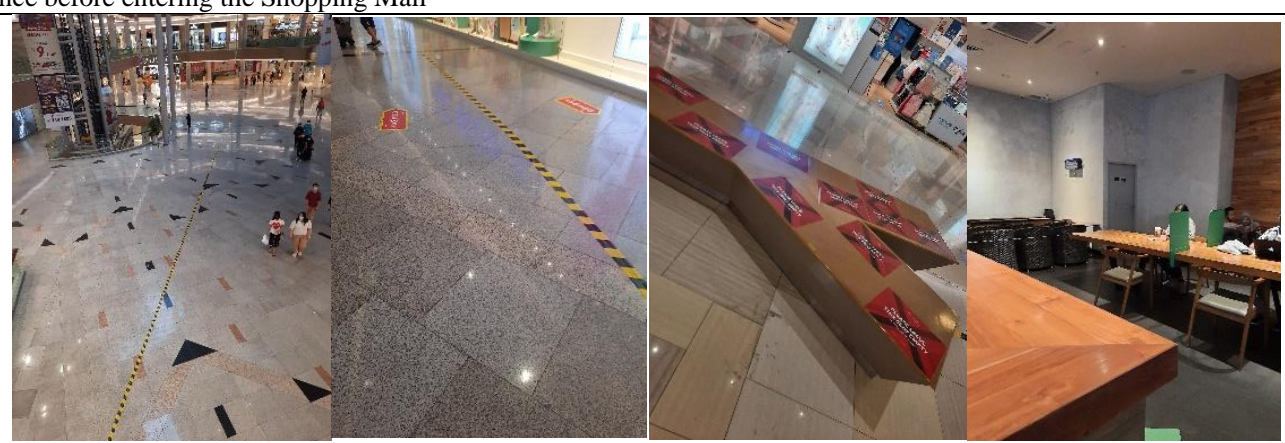

\section{Public Space Area of Shopping Mall}

These pictures are showing that user need to walk based on the instruction and symbols on the floor. There are also symbol that limit the user to use the bench. This is showing that there are more defensible space and more symbol boundary while using the space.
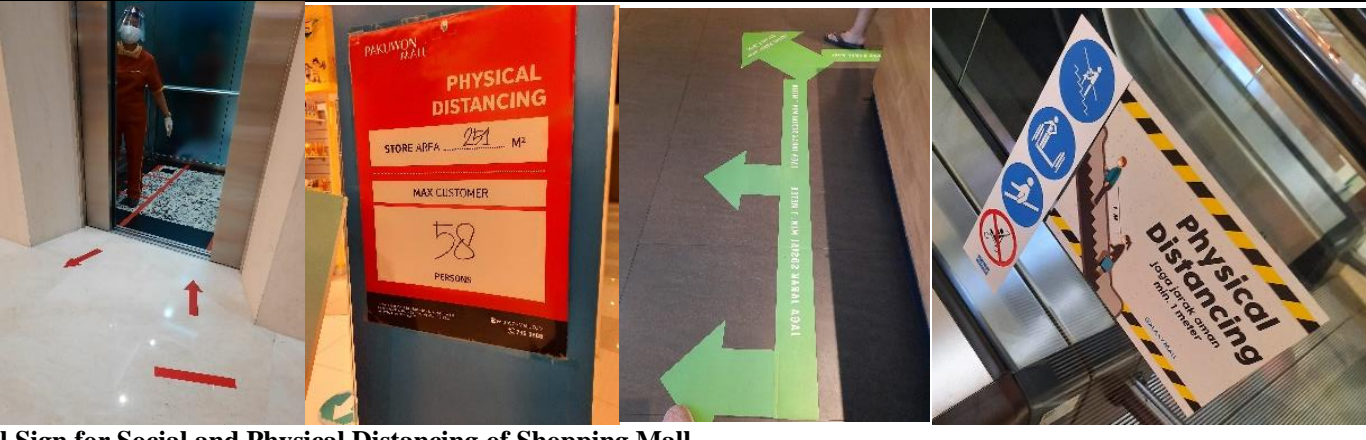

Detail Sign for Social and Physical Distancing of Shopping Mall

These pictures are showing symbol and signage to remind the user to keep social and physical distancing all the time. This signage is become a guideline for people while using the space. This is showing that there are control and symbol boundary in the Shopping Mall 


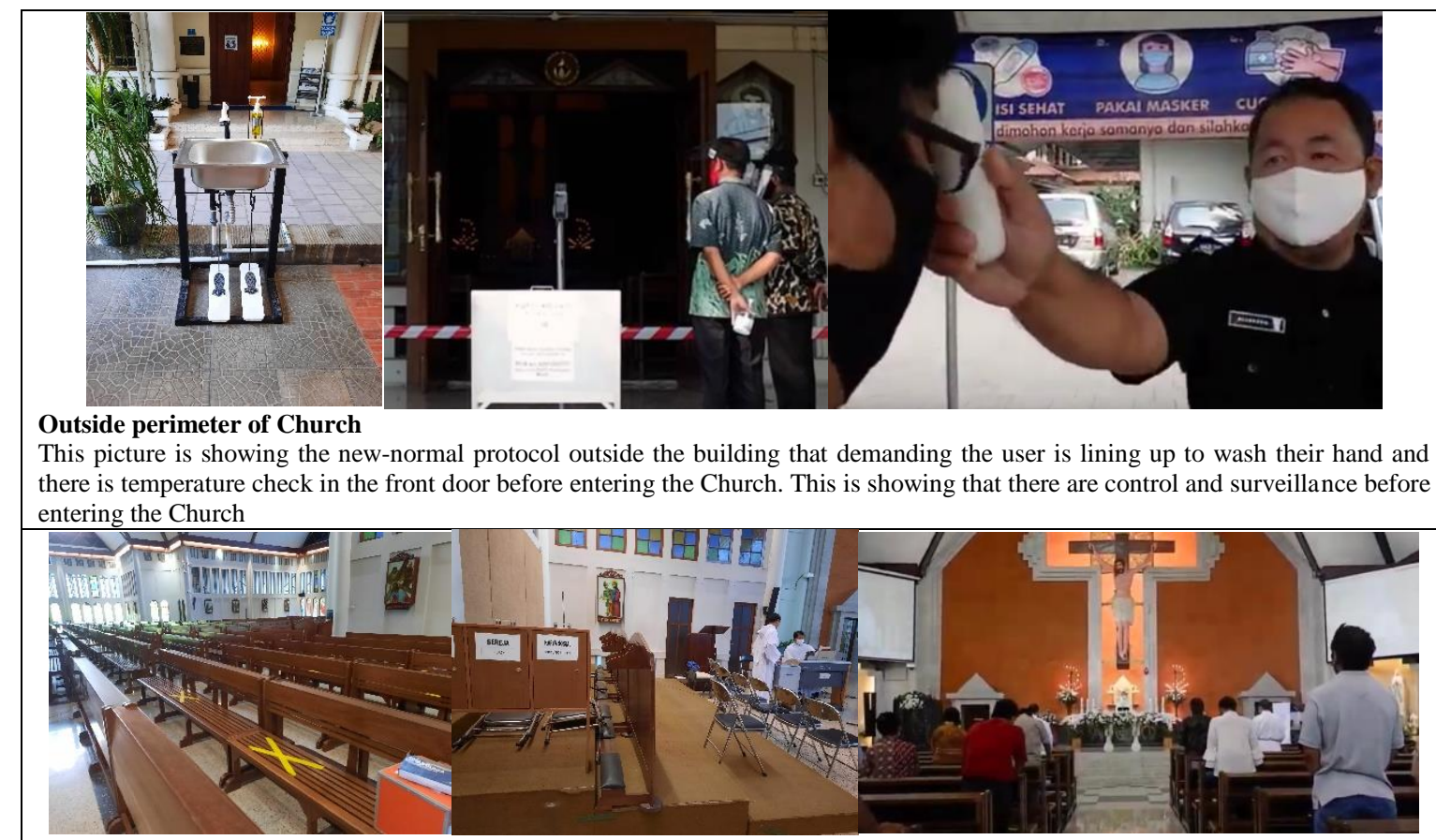

\section{Public Space Area of Church}

These pictures are showing that user need keep social distancing and follow the protocol inside the church. There are also symbol that limit the user to use the bench. This is showing that there are more defensible space and more symbol boundary while using the space.

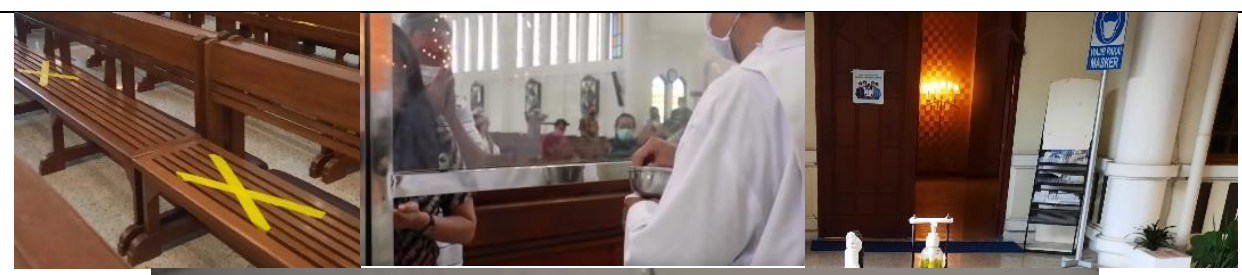

Detail Sign for Social and Physical Distancing of Church

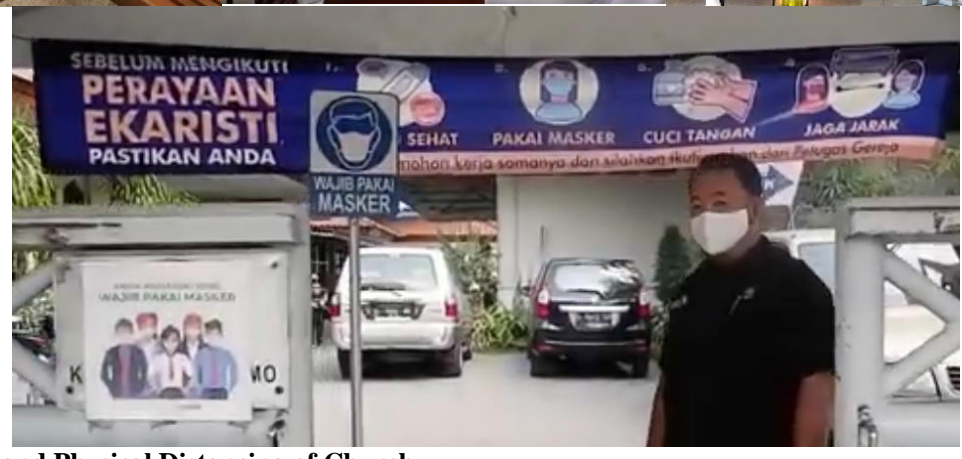

These pictures are showing symbol and signage to remind the user to keep social and physical distancing all the time. This signage is become a guideline for people while using the space. This is showing that there are control and symbol boundary in the Church

Figure 3. Site Observation compilation pictures on Shopping Mall and Church 